\title{
Axel Klein, O'Kelly: An Irish Musical Family in Nineteenth-Century France
}

\section{Adrian Scahill}

\section{(2) OpenEdition}

1 Journals

\section{Electronic version}

URL: http://journals.openedition.org/etudesirlandaises/3998

DOI: $10.4000 /$ etudesirlandaises.3998

ISSN: 2259-8863

\section{Publisher}

Presses universitaires de Rennes

\section{Printed version}

Date of publication: 20 November 2014

Number of pages: 187-192

ISBN: 978-2-7535-3559-6

ISSN: 0183-973X

\section{Electronic reference}

Adrian Scahill, «Axel Klein, O'Kelly: An Irish Musical Family in Nineteenth-Century France », Études irlandaises [Online], 39-2 | 2014, Online since 20 November 2014, connection on 23 April 2019. URL http://journals.openedition.org/etudesirlandaises/3998; DOI : 10.4000/etudesirlandaises.3998 


\title{
Comptes rendus de lecture
}

\author{
Book Reviews
}

Axel KLeIn, O'Kelly: An Irish Musical Family in Nineteenth-Century France, Norderstedt, BoD, 2014.

Axel Klein has made a significant contribution to scholarship on music and Ireland, with the main concentration of his work to date being on the twentieth century. For this extensive volume, however, he has shifted focus away from Ireland and to an earlier period, for a study of the O'Kellys, an extended family of French musicians and composers of Irish origin. Almost nothing has been written on the family since the nineteenth century, so Klein is breaking new ground with this book, which is perhaps more revelatory about music in France than it is about music in Ireland. As he himself recognises in the introduction, the book is also a corrective to what Leon Botstein has described as "the continued dominance in the narrative of musical culture by 'great' music and leading figures", something which "has conspired to block a fuller understanding of the history of musical life and its place and significance in culture and society" ${ }^{1 "}$.

The material is organised into chapters which each focus on a single musician of the family, almost encyclopaedia-like in style - useful in that it allows Klein to present a highly detailed profile of each musician, but which consequently somewhat divorces the material from the wider context of music in France (both in Paris and in the provinces). Perhaps this is to criticise what the book is not, but as a result, it does not clearly position the family within French musical culture. This is borne out by the lack of reference to musicological work on music in nineteenth-century France (for instance the work of Katharine Ellis on music criticism, Anselm Gerhard on music in the theatre, or Frits Noske on French song). That said, the book's undoubted success is in its uncovering of sources which detail the lives and work of these "lesser known composers" (p. 21), as Klein himself describes them.

1. Leon Botstein, "The Eye of the Needle: Music as History after the Age of Recording", in Jane F. Fulcher (ed.), The Oxford Handbook of the New Cultural History of Music (2012), retrieved 12 Aug. 2014 from Oxford Handbooks Online, [http://www.oxfordhandbooks.com/view/10.1093/oxfordhb/9780195341867.001.0001/oxfordhb9780195341867-e-22]. 
Before dealing with the family itself, Klein invests some effort into trying to trace its origins in Ireland, identifying potential links to the O'Kelly de Galway family and the singer and composer Michael Kelly, in an opening chapter which he himself admits is speculative. Because of this, the family's story proper begins in Dublin, where Joseph Kelly (1804-1856) was born. His father, Thomas, moved the family to London at some point after this, and Joseph himself left for Boulogne-sur-Mer in $c$. 1823, where he taught piano before moving to Paris in 1835. Klein suggests that Thomas may have been involved in the music trade as a piano maker, but the sources available inhibit a more definite picture being drawn. Unfortunately this also means that nothing is known about the type of musical education Joseph received, whether this began in Ireland or took place primarily in London, and the identity of his teachers. Whatever the details, his only known composition, a set of quadrilles, suggest he was a highly competent and educated musician.

His avoidance of becoming a naturalised French subject, in his case in order to evade conscription, was followed by other members of the family. The issue of their identity is a naturally complex one given the period in question, with Joseph Kelly asserting himself as a "subject of His British Majesty" (p. 35), but also possibly sending his children to the College des Irlandais in Paris for a period. Three of these children (Joseph, August and George) were to make their living through music, although they would not have been allowed to enter the Conservatoire, as they would have been considered foreign pupils. Klein further suggests that the altering of the family name from Kelly to O'Kelly in 1859 (a step taken by the brothers) was a move made to accentuate the family's Irish identity, which may have been more advantageous to in France than being perceived as English, although this suggestion is not explored in any great detail.

The most notable member of the family was Joseph O'Kelly (1828-1885), the subject of almost half of the book's length. A well-connected and established musician and composer, he was familiar to critics (though not always to his advantage), and popular among the fashionable salons in Paris. At the same time he was not successful enough to avoid having to work for the piano firm of Pleyel-Wolf as a choral conductor and demonstrator, performing at trade fairs and exhibitions. Although Klein in his introduction makes the claim that his music is of "sufficiently high quality to deserve more recognition", the evidence presented doesn't always make a strong case. The piano music included here (and that available in digital editions online) is attractive and melodic, but hardly befitting one who considered themselves a composer-pianist (p. 48, p. 185). Most of it is well within the capabilities of the amateur pianist, and the salon (and the lesson) would seem to be its natural environment. As a performer, it does appear from the text that this was where he was most active, and there is less evidence of his 
appearing in more prominent concerts. For a pianist-composer he seems to have devoted a lot of energy in trying to establish himself as a composer for the stage, writing nine operas (of an admittedly small scale) over the course of his career. The most prominent work for the stage, La Zingarella (1878), was also his low point, as it was generally harshly criticized in the press. Yet his final stage work, La Barbière improvisée (1882), had a significant run, although it too was a one-act comic curtain raiser. He appears to have had more success with his songs, and the Victor Hugo settings seem, from the evidence provided, to be more substantial and adventurous works.

Of all the figures dealt with in the book, it is Joseph who had the closest links with Ireland and Irish musical culture. He was a member of the Anciens Irlandais, an organisation of aristocrats of Irish descent whose activities appear to have been more social than political. Possibly arising out of this connection, he composed the music for a cantata text by the Viscount O'Neill de Tyrone, which was proposed by the Viscount for inclusion at the O'Connell Centenary celebrations in 1875 . The work having been accepted by the festival committee, O'Kelly and O'Neill de Tyrone, along with other Anciens Irlandais members, visited Dublin for the festivities, at which selections from the cantata were performed. Unfortunately the score has been lost, and only scant details about the work are known. Consequent to this, O'Kelly was proposed for the Légion d'Honneur by the Ministry of Foreign Affairs, and was elected (as Irish) in 1881. Aside from the cantata, O'Kelly's works display little enough interest in Ireland or Irish music, and are restricted to some arrangements of familiar tunes (including "The Last Rose of Summer") and a Mac-Mahon Marche (op. 41, OKC 104), probably written for Marshall Patrice MacMahon, a general and politician.

Joseph's brothers Auguste and George were less prominent figures: the former active as a publisher in Paris; the latter returning to Boulogne-sur-Mer to work as a pianist, composer and teacher. Working in a more provincial centre seems to have been advantageous for George, and the dedicatees of his works reveal the mixed nature population of Boulogne. Klein confirms here that it was George, and not Joseph, who composed Le Lutin de Galway, a one-act opera set in Ireland. Although the music is lost, Klein's commentary is perceptive here, and notes that despite the Irish setting, the story itself is not particularly Irish, with particularly the lutin being quite out of place. He suggests that in itself the setting of the opera would have been particularly appealing to the English and Irish community of Boulogne, and it was indeed well received. Other works of George's discussed here include some substantive songs and piano works, which seem comparable to Joseph's output.

Shorter chapters follow on Joseph's son Henri O'Kelly, a pianist, organist and composer; his own son Henri, a bass player and composer; and Auguste's son 
Gustave, also a publisher. These are informative chapters on musicians who had a certain prominence in their day - indeed the first Henri O'Kelly also was made a Chevalier de la Légion d'Honneur - but are since long forgotten, and function as vivid snapshots of the multifaceted activities of working musicians in France. For instance, Henri, who studied at the Paris Conservatoire alongside Debussy, worked out of necessity for most of his career as a church organist and choir director, as well as appearing as a concert pianist, recording piano rolls for Pleyel, and composing both church and secular music.

The final chapter has a wealth of information about non-musical members of the extended family, ranging from brief details of children to more extended profiles of businessmen. While they flesh out the wider family details, it seems of limited relevance for most readers, and I found it quite an abrupt and unsatisfying way to finish end the book - the final sentences concern Raoul O'Kelly, "a simple office employee" (p. 363), who was a German prisoner-of-war in World War II. An additional concluding chapter might have rounded the book off more satisfyingly, providing some estimation of the place of the family within French musical culture, and considering to what extent they can be thought of as being Irish composers. In light of recent work in this area - particularly John Flynn's The Irishness of Irish Music (2009), and Flynn and Mark Fitzgerald's edited volume Music and Identity in Ireland and Beyond (2014) - there is a sense of an opportunity lost here.

The book's substantial appendices commence with an extended family tree, and perhaps the most impressive part of the book is the O'Kelly Catalogue of Works, which collects together all the compositions of the extended O'Kelly family, including works known only through newspaper and other references. Klein includes among the information for each piece places and dates of performances, names and details of dedicatees, and sources, all of which will be invaluable to future scholars working in this area. Having said this, an index of the works discussed would have made it easier to navigate between the biographical and commentary sections. Complementing the catalogue is an appendix with details of the French publishers who published music by the family, their date of foundation, brands, and connections to other publishers (whether taken over by or absorbed into another company).

Klein's industry in producing this substantial book is highly impressive, and its documentation of the biography and the music of these composers will be of much use to future scholars. Having said this, it is very much a first step, and there is much scope for further contextualisation and analysis of these intriguing figures. 